\title{
Development of Student Worksheets Based on Problem Based Learning in Static Fluid
}

\author{
Muslem $^{1}$, M. Hasan ${ }^{2}$, Rini Safitri ${ }^{3}$ \\ ${ }^{1}$ Department Science Education, Postgraduate Program at Syiah Kuala University, Banda \\ Aceh \\ ${ }^{2}$ Department Chemical Education, FKIP Syiah Kuala University, Banda Aceh \\ ${ }^{3}$ Department of Physics, FMIPA Syiah Kuala University, Banda Aceh \\ \{ungohsabe89@gmail.com\}
}

\begin{abstract}
This study aims to describe the feasibility level of worksheet-based PBL on static fluid material in MAN 2 Meulaboh, Aceh. This research is development research with ADDIE type. Data collection is done through the validity sheet of content, presentation and language experts. The research data obtained were analyzed by descriptive percentage. The module feasibility test results by content experts reached $84.10 \%$, presentation experts reached $88.21 \%$, and linguists reached $89.17 \%$. Based on the results of data analysis, it can be concluded that the development of worksheet-based PBL is feasible to apply to the level of SMA / MA.
\end{abstract}

Keywords: Worksheet, model PBL.

\section{Introduction}

Physics is one of the lessons at the high school level that must be studied by science students, who study learning and natural phenomena. According to [1], that the core of physics learning itself includes the processes of science which in learning requires interaction with real objects and interactions with the learning environment. So that students in addition to gaining knowledge and mastering concepts that are learned also increase motivation in learning, then learning physics comes alive. But in reality, this is not the case in MAN 2 Meulaboh, learning that should be dominated by students (student center) but still dominated by teachers (teacher center).

MAN 2 Meulaboh is a madrasa that has a strategic location, close to the city and easily accessible by the community. Even so, the Meulaboh MAN 2 students have a different character from the madrasa/school in the city center, where they seem to be indifferent and not accustomed to digging up their own information from books in the library and the internet.

Physics material has a very prominent characteristic, namely the concepts that are interrelated, meaning that to be able to master a new or certain concept, students must already understand other concepts that are related directly or indirectly to the concepts being studied. This is often encountered by students' complaints about physics lessons. The students always assume that physics is difficult and scary. Apart from the students themselves, the teacher also in the delivery of material cannot be understood by students. This condition is due to physics learning that still applies to learn models that are not in accordance with the concept, not yet 
linking the concepts with the experience of students so that the learning motivation of students is low.

Based on the above problems, it is necessary to have changes and innovations in learning, one of which is the application of appropriate media. One of the learning media to activate students in class is with the student worksheet (LKPD). According to Prastowo [2], LKPD is a printed teaching material in the form of sheets of paper containing material, summaries, and instructions for implementing learning tasks that must be done by students, which refers to the basic competencies that must be achieved. Students gain knowledge and understanding of the concepts learned by conducting activities according to the LKPD instructions, not from teacher explanations. This is in accordance with the demands in the 2013 curriculum.

The type of LKPD that is often encountered so far is only the completion of questions, and many of them are not in accordance with the character and environment of students, so students have no motivation in learning which results in low understanding of physics concepts, therefore the appropriate LKPD needs to be developed by innovating with the learning model. The aim is to innovate the LKPD with a model so that learning is more interesting and students have increased learning motivation so that students are able to master the concept.

Learning so far is still teacher-based, and there have not been two directions. The teacher is still the center of learning (teacher center), so students are less involved and do not understand the material delivered by the teacher. This happens because they have to pursue material so that it is completed when it is approaching the final school exam (UAS). Even though physics is a basic knowledge that is needed by students to support the next level of education. Learning with LKPD accompanied by a problem-based learning (PBL) method provides opportunities for students to be more exploratory based on their abilities so as to create more independent learning and this will change the learning orientation that was initially teacher-centered, then change to center on student activities.

According to Atasoy in Celikler [3] LKPD is a basic tool that consists of steps and processes needed by students and helps students to shape knowledge and participate fully in all class activities at the same time. Yasir, Susantini, \& Isnawati (2013) development of student worksheets based on metacognitive learning strategies to improve student learning outcomes, that worksheets based on metacognitive learning strategies have theoretically feasible limits with a percentage of $91 \%$ (category: very feasible) and empirically based on completeness of outcome indicators learn $99.31 \%$. The learning outcomes are in accordance with KKM standards, namely $75 \%$ can be said to be suitable for use. Wijayanti [5] that the quality of LKS greatly influences students' learning motivation.

Various development studies have been carried out before, that LKPD affects the creativity of students. [6], that LKPD influences students' competencies. Yildirim, Sevil, \& Alipasa (2011) that learning by using LKS can improve student learning achievement. The results of the Pariska, Elniati \& Syafriandi [8] study, that the application of learning using PBL-based worksheets can encourage students to think creatively. The research of [9], the results of the study showed that learning using LKS was more effective in improving student learning outcomes than learning with conventional models. Research conducted by Indriani, Murtiani \& Gusnaedi[10] states that learning by using LKS can improve student learning outcomes.

Based on the background of the problem and the definition above, to solve the problem of the difficulties of students in static fluid material at Meulaboh MAN 2 it is necessary to develop PBL based LKPD because PBL is one of the learning models that can be used to develop students' mindsets and make students active. In accordance with the opinion of Nata [11], problem-solving learning is a continuation of learning understanding, learning is directed at helping students restructure the situation they face in order to solve problems. 


\section{Methods}

This research is an ADDIE type of development research, namely the development of PBLbased LKPD on static fluid material. The steps of research and development through the ADDIE model Sugiyono[12] are as follows:

a) The analysis is a process of defining what students will learn. So to know or determine what must be learned, we must do several activities, including:

1) Conducting needs assessment analysis, namely to determine the abilities or competencies that students need to learn, the analysis referred to in this study is an analysis of increasing understanding of concepts and learning motivation of students that is influenced by the application of PBL-based LKPD.

2) Analyze task analysis (task analysis) which is to find out and clarify whether the problem faced requires a solution in the form of learning devices. Therefore, the output to be produced is in the form of characteristics or profiles of prospective participants, identification of gaps, identification of needs and detailed task analysis based on needs.

b) Design, this stage is also known as the term making a design by formulating a design including:

1) Determine learning objectives.

2) Prepare a test, where the test must be based on the learning objectives that have been formulated.

3) Determine the right learning strategy by using the discussion method to achieve that goal.

4) Making PBL based LKPD.

c) Development is the process of realizing design into reality, then the development of PBLbased LKPD is carried out. One important step in the development phase is a trial before implementing limited class trials (small classes). This trial phase is indeed part of one of the ADDIE steps, namely evaluation. More precisely formative evaluation, because the results are used to improve the learning system that we are developing.

d) Implementation is a real step to implement PBL-based LKPD. At this stage PBL-based, LKPDs that have been developed are arranged in such a way according to their roles or functions that they can be implemented according to the initial design. The implementation referred to in this study is to conduct a limited-scale trial in the classroom and even apply it to learning with the aim of improving students' conceptual understanding.

e) Evaluation, the process to see whether the PBL-based LKPD that is being developed is successful or not and whether it is in accordance with initial expectations or not. Evaluations that occur in each of the four stages above are called formative evaluations because the purpose is for revision needs. For example, at the design stage, maybe we need one form of formative evaluation such as an expert revision to provide input to the design we are making. At the development stage, it may be necessary to try out a product that we have developed or maybe need a small group evaluation and others.

The flow of research and development through the ADDIE model is as Figure 1: 


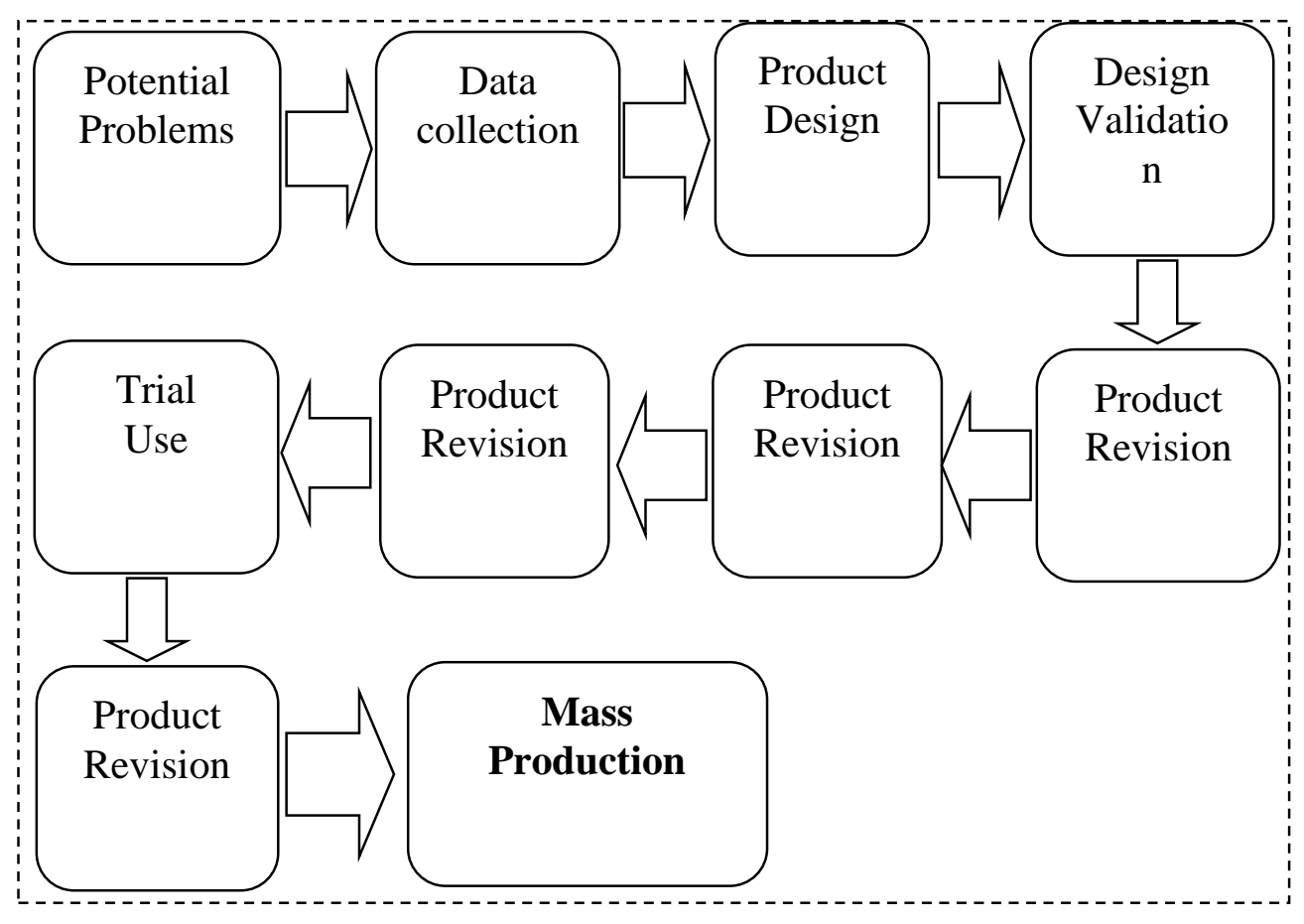

Figure 1. Step in Development Research (Source: Sugiyono, 2006 )[12]

\section{Result and Discussion}

Phase I validation obtained $100 \%$ positive answers for all assessment points from all experts. Based on these results it can be said that the developed LKPD passed the stage I validation and was reassessed in stage II validation. Phase II validation can be carried out with the requirements for stage I validation, the percentage obtained is $100 \%$ or all experts give a positive assessment. The recapitulation of the results of Phase I expert assessment of the module can be seen in Table 1.

LKPD that have passed stage I are reassessed more deeply in stage II validation which was carried out 2 times, namely before limited scale trials and before large-scale trials. Based on the results of the validation before the limited scale trial it can be seen that the LKPD developed shows the results of the Content (Content) expert validation of $71.48 \%$ included in the criteria of "feasible", structural experts showed $83.75 \%$ included in the criteria "very feasible" and linguists show results of $84.03 \%$ included in the criteria of "very decent". 
Table 1. Data Recapitulation of Phase I Validation Results by Experts on LKPD

\begin{tabular}{ccccc}
\hline \multirow{2}{*}{ No } & Validation & \multicolumn{2}{c}{$\begin{array}{c}\text { Percentage of } \\
\text { Assessment }\end{array}$} & Criteria \\
\cline { 3 - 4 } & & $\mathbf{1}$ & $\mathbf{2}$ & \\
\hline 1. & Content Expert (Content) & 100 & - & Get away \\
\hline 2. & Structural Specialist & 100 & - & Get away \\
\hline 3. & Language Specialist & 79 & 100 & Get away \\
\hline
\end{tabular}

Based on these results it can be said that the static fluid LKPD that has been developed is declared feasible and can be tested on a limited scale trial. Data recapitulation from the results of stage II expert validation on LKPD can be seen in Table 2.

Table 2. Recapitulation of Data on Phase II Validation Results by Experts on LKPD

\begin{tabular}{ccccc}
\hline \multirow{2}{*}{ No } & \multirow{2}{*}{ Validation } & \multicolumn{2}{c}{ Percentage } & \\
\cline { 3 - 4 } & & Stage & Stage & Criteria \\
\hline 1. & Content Expert (Content) & 71,48 & - & Worthy \\
\hline 2. & Structural Specialist & 83,75 & - & Very Worthy \\
\hline 3. & Language Specialist & 62,50 & 84,03 & Very Worthy \\
\hline
\end{tabular}

After a limited scale trial was carried out, re-validation was carried out before a large-scale trial was made known that the LKPD developed showed positive results of content expert validation (content) of 85.09 and 95.74 included in the criteria of "very feasible" structural experts. , 03 and 96.53 included in the criteria of "very decent" and linguists showed the results of 94.58 included in the criteria of "very feasible". Recapitulation of data from expert validation results before a large-scale trial of LKPD can be seen in Table 3.

Table 3. Recapitulation of Data on Phase II Validation Results by Experts on LKPD before Trial Extensive Scale

\begin{tabular}{ccccl}
\hline \multirow{2}{*}{ No } & \multirow{3}{*}{ Validation } & \multicolumn{2}{c}{ Percentage } & \multirow{2}{*}{ Criteria } \\
\cline { 3 - 4 } & & Stage & Stage & \\
\hline 1. & Content Expert (Content) & 85,09 & II & \\
\hline 2. & Structural Specialist & 84,74 & Very Worthy \\
\hline 3. & Language Specialist & 94,58 & - & Very Worthy \\
\hline
\end{tabular}

During the validation process, suggestions and comments are given by experts. The several improvements to the LKPD that have been carried out are presented in Table 4. 
Table 4. LKPD Evaluation and Revision Results

\begin{tabular}{|c|c|c|}
\hline No & Suggestions / Comments & Repair \\
\hline 1. & $\begin{array}{l}\text { Images need to be clarified again and based } \\
\text { on facts in the field in accordance with the } \\
\text { Aceh region. }\end{array}$ & $\begin{array}{l}\text { Reviewing the images on the LKPD that } \\
\text { need to be repaired, clarifying the images, } \\
\text { and adding images that are appropriate to } \\
\text { the environment around Aceh. }\end{array}$ \\
\hline 2. & The image display must be colored and large & $\begin{array}{l}\text { Review the images and replace them with } \\
\text { large, colorful images to make them clearer }\end{array}$ \\
\hline 3. & $\begin{array}{l}\text { Procedure for writing that is not in } \\
\text { accordance with EYD }\end{array}$ & $\begin{array}{l}\text { Reread and correct writing that is not yet } \\
\text { standard and not in accordance with EYD, } \\
\text { by referring to the dictionary of the } \\
\text { Indonesian language dictionary. }\end{array}$ \\
\hline 4. & $\begin{array}{l}\text { Combine color and writing well so that it is } \\
\text { eye-catching. }\end{array}$ & $\begin{array}{l}\text { Review the colors on the LKPD and consult } \\
\text { with experts to create a good color } \\
\text { combination. }\end{array}$ \\
\hline 5. & Latest literature & Search for and add the latest literature. \\
\hline 6. & $\begin{array}{l}\text { Re-check the LKPD steps and suitability } \\
\text { with the PBL model steps }\end{array}$ & $\begin{array}{l}\text { Check the LPKD steps and adjust the steps } \\
\text { of the PBL model. }\end{array}$ \\
\hline 7. & $\begin{array}{l}\text { Material needs to be added and sample } \\
\text { questions. }\end{array}$ & $\begin{array}{l}\text { Add static fluid material along with sample } \\
\text { questions. }\end{array}$ \\
\hline 8. & Cases must be contextual & $\begin{array}{l}\text { Revise the case of contextual static fluid } \\
\text { material. }\end{array}$ \\
\hline
\end{tabular}

\section{Conclusion}

Based on the problems of data analysis the results of the study can be concluded that PBLbased LKPD developed is suitable for physics learning at the high school level.

\section{REFERENCES}

[1] D. Yulianti and Wiyanto, Perancangan pembelajaran inovatif. Semarang: LP2M Universitas Negeri Semarang, 2009.

[2] A. Prastowo, Panduan kreatif membuat bahan ajar inovatif. Yogyakarta: Diva Press, 2012.

[3] D. Celikler, "The effect of worksheets developed for the subject of chemical compounds on student achievement and permanent learning," Int. J. Reseacrh Teach. Educ., vol. 1, no. 1, pp. 42-51, 2010.

[4] M. Yasir, E. Susantini, and Isnawati, "Pengembangan Lembar Kerja Siswa (LKS) Berbasis Strategi Belajar Metakognitif Untuk Meningkatkan Hasil Belajar Siswa Pada Materi Pewarisan Sifat Manusia,” BioEdu, vol. 2, no. 1, pp. 77-83, 2013.

[5] E. Wijayanti, "Kualitas lembar kerja siswa," 2008.

[6] Y. D. Amalia, Asrizal, and Z. Kamus, "Pengaruh penerapan LKS berorientasi pembelajaran berbasis masalah terhadap kompetensi siswa kelas X SMA negeri 1 gunung talang," Pillar Phys. Educ., vol. 4, pp. 17-24, 2014.

[7] N. Yildirim, K. Sevil, and A. Alipasa, "The effect of the worksheet on students' achievement in chemical equilibrum," J. Turkish Sci. Educ., vol. 8, no. 3, 2011. 
[8] I. S. Pariska, S. Elniati, and Syafriandi, "Pengembangan lembar kerja siswa berbasis masalah,” J. Pendidik. Mat., vol. 1, no. 1, pp. 75-80, 2012.

[9] H. Özmen and N. Yildrim, "Effect of work sheets on student's success : Acids and bases sample," J. Turkish Sci. Educ., vol. 2, no. 2, pp. 10-13, 2005.

[10] W. Indriani, Murtiani, and Gusnaedi, "Pengaruh penerapan LKS berbasis strategi pembelajaran peningkatan kemampuan berpikir (SPPKB) terhadap keterampilan berpikir kreatif siswa," Pillar Phys. Educ., vol. 2, pp. 145-152, 2014.

[11] A. Nata, Perspektif islam tentang strategi pembelajaran. Jakarta: Kencana Prenada Media Group, 2011.

[12] Sugiyono, Metode penelitian kuantitatif kualitatif dan R \& D. Bandung: Alfabeta, 2006. 